Preprint for

Dunaetz, D. R. (2021). The importance of hypotheses in church-based research. Great Commission Research Journal, 13(1), 5-18.

\title{
The Importance of Hypotheses in Church-Based Research
}

\author{
David R. Dunaetz, Editor
}

\begin{abstract}
The role of hypotheses is central both in church-related research and in Christian ministry. Hypotheses guide the collection of data to determine what is true in research and provide tentative guidelines for action in ministry, even when they are not yet confirmed. Well-constructed hypotheses are based on previous research and provide clear potential solutions to research problems. They succinctly posit a testable relationship between two or more variables. Such hypotheses can be tested through appropriately designed research. Statistical techniques can indicate to what degree the evidence collected supports the hypotheses. In church-based research, hypotheses to be examined can come from a body of literature (e.g., the Church Growth Movement), a practitioner's experience, theories from other domains (e.g., the Social Brain Hypothesis; Dunbar, 1993), and modeling phenomena using analogies (e.g., modeling the church lifecycle as an epidemic; Hayward, 2015, 2018).
\end{abstract}




\section{The Importance of Hypotheses in Church-Based Research}

Church-based research is not simply collecting data and discovering what it says. If we have access to data from churches, it is most likely that the data provided does not record all the information that could be useful in understanding what is happening in the churches. Certainly, if we have specific questions that we are trying to answer, such as "What elements of worship are most effective for evangelism?", “How do church members understand baptism?”, or "Do fundamentalist churches have a more authoritarian structure than non-fundamentalist churches?", very specific information will need to be collected. To ensure that the appropriate data is collected, researchers propose specific hypotheses that will guide the research design so that the data collected can be analyzed in such a way that will lead to some type of conclusion concerning the truth of these hypotheses.

Sometimes hypotheses are not the beginning of research design (as is typical in quantitative research) but are the results of research (which is common in qualitative research). When researchers seek to initially understand a phenomenon, they may collect data from several examples or interview various people who have first-hand knowledge of this phenomenon and then make subjective conclusions or hypotheses about the phenomenon. Such an approach has been common in much church-based research focusing on effective evangelism and church planting (McGavran, 1955; Moon, 2020; Wagner, 1989). However, the hypotheses proposed in such qualitative studies are often tentative. More rigorous quantitative studies testing of these hypotheses can find stronger evidence to support them, or the studies can find that the additional evidence does not support them.

In order to form high-quality hypotheses for research and practice, let us examine some important concepts related to hypothesis creation. 


\section{Research Problems, Research Questions and Hypotheses}

The best research provides solutions to problems that we face. In Great Commission-focused research, these problems typically concern understanding how to better obey and fulfill the Great Commission (Matt. 28:18-20) in various contexts. These problems may be quite general, such as the difficulties involved in bringing the gospel to and making disciples in closed countries (also known as creative access countries; Barnett, 2005), or they can be rather narrow, such as the difficulties that first-time attenders have in connecting with people at a megachurch. If we want to find a solution to these problems through research, these problems can be considered research problems. Clearly identifying the research problem enables us to focus our research and makes it more likely that a solution will be found. In our examples, the research problems might be phrased as "Missionaries are often ineffective in creative access countries" and "First-time visitors to American megachurches often leave without warm, personal interaction with church members, resulting in feeling that the church is cold and unwelcoming."

After we define the research problem, we need to find a research question, a question the response to which will help solve the research problem. The response might not completely solve the problem, but it should provide a partial solution that leads us to better understand what we can do to better address the problem. For a given research problem, the research question can be broad or narrow. For example, "How do effective missionaries (versus ineffective missionaries) share the gospel in creative-access countries?" and "Does having a large number of followers on local social media (versus fewer followers) lead to more opportunities to share the gospel in face-to-face situations for missionaries in creative-access countries?" are both useful research questions. The more narrow or specific the question is, the easier it will be to design appropriate research that will provide at least a partial solution to the research problem. For the problem concerning our example of first-time visitors at megachurches, we can use research questions such as "How have recently baptized church members (who did not 
know anyone in the church the first time they attended) met people and developed relationships?" or "Are visitors more likely to meet someone in megachurches that use individual seats or in the megachurches that use pews?"

Once the researcher has limited the scope of the research to a specific research question, the search for a testable hypothesis can begin. A hypothesis is a statement that, if true, provides at least a partial solution to the research problem. It is a statement that answers the research question or at least contributes to a partial answer. The following list (Dunaetz, 2020) provides some characteristics of a good hypothesis from a scientific point of view:

1. It is a response to a research question clearly expressed in a declarative statement.

2. It posits a relationship between two or more variables.

3. It reflects a theory or body of literature upon which it is based.

4. It is brief and to the point.

5 . It is testable.

Since one of the principal reasons that we make hypotheses in research is to decide if it is supported by the evidence or not, the hypothesis needs to be expressed as a clear declaration of a potential fact that can be either supported or not supported by whatever data we collect. "First-time visitors meet lots of people in churches with chairs" is too vague for research purposes. "Firsttime visitors meet more people in churches with chairs than in churches with pews" is much clearer and more specific, making it more suitable for a research hypothesis.

Secondly, a good hypothesis needs to posit a relationship between two or more variables. A variable is anything that can be measured which can take on different values according to the context. In our example with pews and chairs, the first variable is the type of seating. In a study of $21^{\text {st }}$ century American megachurches, chairs and pews might be the only types of seating that interest us. In other contexts, we might include standing or sitting on a rug as possible values that this variable can take on. For 
each church in our study, we would record the type of seating they have. The second variable would be the number of warm interactions that first-time visitors have. This would be a numeric value, perhaps typically between $\mathrm{o}$ and 5 . This variable would be more difficult to measure than the type of seating in a church. We could develop some type of survey for first-time visitors to complete, or we could be more creative and study a high-resolution video recording of the audience before and after the service, assuming we would be able to identify who the first-time visitors were.

The third criteria for good research hypotheses is that the hypothesis is based on some theory or body of literature. There should be a theoretical reason that the hypothesis might be true. By having an idea of why something is true, we can better examine the precise conditions under which it will be true and better know how to adapt the hypothesis to other contexts. For example, the hypothesis concerning warm interactions and church seating is based partially on the concept of psychological safety (Baer \& Frese, 2003; Edmondson \& Lei, 2014), the degree to which a person feels safe in undertaking a risky behavior (such as introducing themselves to someone). Families or affinity groups typically may leave a greater distance between themselves and strangers in pews (perhaps 24 to 48 inches) than they do in chairs (typically one chair, typically with a width of 22-24 inches) because the undefined borders of personal space in pews makes sitting close less psychologically safe. It is likely to be easier and more natural to start a warm interaction with someone when they are within 24 inches from the initiator than when they are more distant, hence the chairs versus pews hypothesis.

The fourth criteria of a good research hypothesis is that it is brief and to the point. It is one thing to find evidence that supports a hypothesis which can contribute to fulfilling the Great Commission, but it is altogether different to propagate the conclusions and have people integrate them into their life and ministry. The more clearly and concisely the hypothesis and the resulting conclusions can be stated, the more likely they are to be accepted by a wide audience.

The final criteria is that the hypothesis needs to be testable. Unless we can collect data that provides evidence that a hypothesis 
is true or not, the hypothesis simply remains an educated guess. However, if we can test our hypothesis, and if there is strong evidence to support it, the hypothesis moves into the shared body of knowledge concerning a phenomenon, often called theory. For example, if data supported the hypothesis that first-time visitors to megachurches have more warm social interactions in churches with chairs rather than in churches with pews, the importance of using chairs would move more solidly into church growth theory.

\section{Testing Hypotheses}

But how would we actually test this hypothesis? This is where a hundred years of advances in statistics and the social sciences becomes very useful. Before the data is collected, the research needs to be designed carefully so that it is most likely to provide us with the data needed. For example, data from 1000 visitors in 30 megachurches (15 with chairs and 15 with pews) could provide the information needed. If the data indicates that the visitors had an average of 2.00 warm interactions in churches with chairs and 1.00 warm interactions in churches with pews, this would provide evidence that supports the hypothesis (these numbers are chosen for convenience; I suspect that they might be lower in some churches). The strength of the evidence would depend on the specific statistical approach and the validity of the research design.

We could simply say that 2.00 warm interactions in the churches with seats is greater than 1.00 warm interactions in the churches with pews, so we conclude that chairs are superior to pews. This is the simplest way to test a hypothesis. We look at the various options and decide which one the evidence points to. This might be the most common approach in qualitative research (Creswell \& Poth, 2016; Patton, 2014) and theology (Lewis \& Demarest, 1996). As always in research, this approach is heavily dependent on logic and the quality of the data available to the researcher. But this approach is also limited by human biases and heuristic thinking. When faced with ambiguous information, as Francis Bacon (1620/1902) said, we prefer to believe what we prefer to be true. The difference between 2.00 warm welcomes and 1.00 warm welcomes is pretty large, but if the two values were .80 warm 
welcomes and .70 warm welcomes, would we conclude that the difference is certain enough and large enough to justify the conclusion that chairs are better than pews?

To reduce some of the uncertainties associated with data, statisticians use the concept of null hypothesis significance testing (Fisher, 1925) to determine if we can be reasonably sure or not that the data supports a hypothesis. If we want to know if our research hypothesis is strongly supported by the data, we can look at the opposite of the hypothesis, which is known as the null hypothesis because it includes the possibility that the relationship that we seek to confirm does not exist. For example, if our hypothesis is "Firsttime visitors meet more people in churches with chairs than in churches with pews," then our null hypothesis would be "First-time visitors do not meet more people in churches with chairs than in churches with pews" or, its logical equivalent, "First-time visitors in churches with chairs meet the same number or fewer people in churches with pews."

The value of the null hypothesis is that it includes the idea that nothing happens because of the variable under consideration (e.g., the seating used by churches), that is, any differences are due to chance. Now, when things happen by chance, especially things related to human behavior, their outcomes are typically normally distributed, that is, their frequency is distributed as a bell curve. For example, if the average person meets 1.00 people, that means that quite often they meet 1 person, but sometimes $\mathrm{o}$ or 2 people; occasionally they might meet 3 people, but it would be very rare for them to meet 100 people. Statisticians have a very good understanding of what types of results we should expect if things happen by chance. This means that if we have data, we can calculate the probability of obtaining such data if it were simply due to chance (i.e., the null hypothesis is true). Scientists generally agree on the convention that when these probabilities are less than $5 \%$ (less than 1 chance out of 20), then we have strong evidence that the results did not happen by chance, that is, the null hypothesis is very likely not true. Now if the null hypothesis is not true, then, by logical necessity, our research hypothesis is true. Hence if the calculated probability of the data occurring by chance is less than $5 \%$ (i.e., $p<$ 
.05), then we have found strong objective evidence that our research hypothesis is true, and this despite any subjective biases that we might have. If $p<.05$, we say that the hypothesized relationship or difference is statistically significant, meaning that we have good reason to believe that it is true, and that the data is not the spurious result of chance.

When testing a hypothesis, we also need to consider whether it is a directional hypothesis (e.g., visitors will meet more people in churches with chairs than in churches with pews) or exploratory, also known as a non-directional hypothesis (e.g., visitors will meet a different number of people in churches with chairs than in churches with pews). Normally, we want to make a directional hypothesis; it is easier to reach statistical significance if we are only looking for a difference in one direction. Directional hypotheses are also known as one-tailed hypotheses because we're only looking for the probability of events happening by chance in one tail of the bell curve. However, if we are not sure of what direction the results are going to go (e.g., we have a theoretical reason that pews might be better than chairs as well as a theoretical reason that chairs might be better than pews), we should make the non-directional hypothesis that the number of people met in the two types of churches will be different. It is more difficult to reach statistical significance with this type of study (we have to look at both tails of the normal distribution), but if the data is statistically significant in either direction $(p<.05)$, then we can make a conclusion about which of the two theories is better in our context.

\section{The Origin of Hypotheses}

Where do hypotheses come from? There is no limit to the source of hypotheses, but experience indicates that some routes are more fruitful than others. In the early days of the Church Growth Movement, many of the hypotheses came from the writings of Donald McGavran (McGavran, 1955; McGavran \& Wagner, 1990) as described by Charles Arn (2021) in this issue of the Great Commission Research Journal. Other church growth hypotheses grew out of biblical concepts and the experiences of church consultants and practitioners (Arn, 1987; McIntosh, 1999, 2003; Moon, 2020). 
Exploratory hypotheses can come from a synthesis of best practices and folk wisdom. Dunaetz and Priddy (2014) explored the veracity of truisms associated with church growth (such as "Churches that emphasize prayer grow faster than those which do not" or "Churches which emphasize foreign missions grow faster than those which do not.") by examining pastoral attitudes to determine what drove church growth. The results indicated some truisms were supported by the data, while others were not (e.g., prayer predicted church growth while emphasizing world missions did not.).

Other academic disciplines are also a rich source of hypotheses, often contributing to theory that provides causal explanations for church-based phenomena, rather than simply describing what is observed (Hayward, 1999). Hypotheses related to evangelism, discipleship, and church life can come from such fields as history (Hellerman, 2003), cultural psychology (Hunter, 1996), leadership theory (Lim, 2004), and psychology (Dunaetz et al., 2018). Reflections on contemporary events also serve as sources of hypotheses relevant to the Great Commission, such as the COVID19 pandemic (Rainier, 2020) or, as in this issue of the journal, China's growing influence in the world (Lee, 2021).

\section{Church-Related Hypotheses from the Social Brain Hypothesis}

As the study of the growth of churches develops, the theory explaining the phenomena that have been observed grows as well. For example, Bretherton and Dunbar (2020) of the University of Lincoln (UK) have applied Dunbar's (1993) social brain hypothesis to the growth and functioning of churches. The social brain hypothesis states that human brains are limited to forming cohesive groups with a maximum size of approximately 150 members. Once a group grows much past 150, group cohesion decreases because we cannot have an especially meaningful relationship with everyone in the group due to our cognitive limitations. This provides a theoretical framework for understanding congregational growth and structure based on human brain capacity. It leads to several very specific hypotheses (Bretherton \& Dunbar, 2020) describing 
phenomena that have been noted in church growth literature.

Member engagement and participation will be lower in larger churches than in smaller churches. Because group cohesion is lower when churches are much larger than 150 people, there will be an increase in freeloading, with a relatively larger fringe group than in smaller churches. This phenomenon has long been observed in churches (Hussey, 2016; von der Ruhr \& Daniels, 2012; Wicker, 1969; cf. Dunaetz, 2021).

Churches with more than 150 people need to have smaller groups. For members to feel that they are an important part of the group, typically groups of 150 or less are needed. The exact upper limit depends on the personality mix, the culture, and the social expectations of the group's members. Most churches are under the 150 person limit, so they can function as a cohesive whole (McIntosh, 1999). Larger churches, in contrast, often have extensive small group ministries to meet their members' needs for community (Hartwig et al., 2020; Wuthnow, 1994)

Churches will struggle with restructuring to grow beyond 150 people. In churches with less than 150 people, the church functions as a cohesive whole where everyone knows each other. However, this unified whole cannot exist if it continues to grow. Once a church reaches approximately 150 people, visitors and potential new members are less likely to be integrated into the community because the existing members have little ability to develop relationships with new people (George \& Bird, 2017; Wagner, 1990). To continue growing, the church as a whole cannot be each member's primary social group. This will require some type of reorganization, typically with a second staff person added, that permits the creation of other entities that serve as primary social group; such reorganization can lead to struggles and conflict because existing members do not want to lose what they value.

Although these three hypotheses (Bretherton \& Dunbar, 2020) describe well-documented phenomena, having a theoretical framework such as the social brain hypothesis (Dunbar, 1993) to understand why they occur provides a structure for developing more effective strategies to address the problems associated with the phenomena. 


\section{Creating Hypotheses with Analogies: Modeling the Church Lifecycle as an Epidemic}

One approach to developing hypotheses is to look for similarities between an observed phenomenon (e.g., the growth and decline of churches) and a phenomenon in another domain (Wicker, 1985). It has long been observed that churches have life cycles, typically described by slow initial growth, followed by more rapid growth, plateauing, and then a gradual decline (Arn, 1985; Malphurs \& Penfold, 2014; McIntosh, 2009; Moberg, 1962). John Hayward of the University of South Wales recognized that this cycle was similar to the spread of a pandemic and its eventual decline (Hayward, 1999, 2005). Using what we know about pandemics, he has developed a mathematical model that assumes that the gospel and conversions propagate like viruses and infections: A few people are very contagious, infect others, and gradually become less contagious, resulting in fewer infections. People eventually become immune or die off, resulting in a long slow decline of the number infected.

This model (Hayward, 1999, 2005) leads to a number of hypotheses that are not especially common in ministry-focused circles, but which might be true:

a. Conversion growth is highly correlated with contact between believers who are effective evangelists and nonbelievers.

b. People who are effective evangelists tend to be effective for a limited period of time.

c. A few people who are very effective in evangelism (superspreaders) have a greater impact on the church than many people who are only mildly effective.

d. In populations with few Christians, initial church growth will be very slow.

e. When large parts of a population are Christians, periods of growth will not last long.

f. Church growth doesn't end because of secularisation, but because effective evangelists disappear or have no contact with non-Christians. 
Such modeling and hypotheses permit us to think about evangelism, social networks, and spiritual gifting in ways that could lead to fruitful research and insights concerning effective ministry.

\section{Conclusion}

We have seen that hypotheses play an essential role in church-based research and practice. Clear statements concerning how behaviors, concepts, and other church-related phenomena relate to each other serve as a guide for future research, provide tentative guidelines for present ministry, and may be used as a tool for evaluating what we are currently doing and evaluating what we have done in the past. My prayer for all of the readers of the Great Commission Research Journal and for each member of the Great Commission Research Network is that they develop solid hypotheses which describe human behavior and responses in church-based ministry, that they collect data to evaluate whether they are true, and that they communicate their conclusions to others who can benefit from their research so that the Great Commission can be fulfilled in ever more effective ways.

\section{David R. Dunaetz, General Editor}

\section{References}

Arn, C. (2021). My pilgrimage in Church Growth. Great Commission Research Journal, 13(1), 61-85.

Arn, W. (1985). Is your church in a mid-life crisis? The Win Arn Growth Report, 7, 1-2.

Arn, W. (1987). The Church Growth ratio book: How to have a revitalized, healthy, growing, church. Church Growth, Inc.

Bacon, F. (1620/1902). Novum organum (J. Devey, Ed.). P. F. Collier \& Son.

Baer, M., \& Frese, M. (2003). Innovation is not enough: Climates for initiative and psychological safety, process innovations, and firm performance. Journal of Organizational Behavior, 24(1), 45-68.

Barnett, M. (2005). Creative access platforms: What are they and do we need them? Evangelical Missions Quarterly, 41(1), 88-96.

Bretherton, R., \& Dunbar, R. I. M. (2020). Dunbar's number goes to church: The social brain hypothesis as a third strand in the study of church growth. Archive for the Psychology of Religion, 42(1), 63-76. 
Creswell, J. W., \& Poth, C. N. (2016). Qualitative inquiry and research design: Choosing among five approaches. Sage.

Dunaetz, D. R. (2020). Research methods and survey applications: Outlines and activities from a Christian perspective (3rd ed.). Martel Press.

Dunaetz, D. R., Jung, H. L., \& Lambert, S. S. (2018). Do larger churches tolerate pastoral narcissism more than smaller churches? Great Commission Research Journal, 10(1), 69-89.

Dunaetz, D. R., \& Priddy, K. E. (2014). Pastoral attitudes that predict numerical Church Growth. Great Commission Research Journal, 5, 241-256.

Dunaetz, D. R., Smyly, C., Fairley, C. M., \& Heykoop, C. (2021). Values congruence and organizational commitment in churches: When do shared values matter? Psychology of Religion and Spirituality, Advance online publication.

Dunbar, R. I. M. (1993). Coevolution of neocortical size, group size and language in humans. Behavioral and Brain Sciences, 16(4), 681-694.

Edmondson, A. C., \& Lei, Z. (2014). Psychological safety: The history, renaissance, and future of an interpersonal construct. Annual Review of

Organanizational Psychology and Organizational Behavior, 1(1), 23-43.

Fisher, R. A. (1925). Statistical methods for research workers. Oliver and Boyd.

George, C. F., \& Bird, W. (2017). How to break growth barriers: Revise your role, release your people, and capture overlooked opportunities for your church. Baker Books.

Hartwig, R. T., Davis, C. W., \& Sniff, J. A. (2020). Leading small groups that thrive. Zondervan.

Hayward, J. (1999). Mathematical modeling of church growth. Journal of Mathematical Sociology, 23(4), 255-292.

Hayward, J. (2005). A general model of church growth and decline. Journal of Mathematical Sociology, 29(3), 177-207.

Hellerman, J. H. (2003). When the church was family: Revisioning Christian community in light of ancient social values. Great Commission Research Journal, 14(3), 19-37.

Hunter, G. G., III. (1996). The rationale for a culturally relevant worship service. Great Commission Research Journal, 7, 131-144.

Hussey, I. (2016). The big news on small churches: Re-evaluating the contribution of small churches to the fulfillment of the great commission. Great Commission Research Journal, 7(2), 172-183.

Lee, P. (2021). China's belt and road initiative: Mission opportunities and challenges. Great Commission Research Journal, 13(1), 19-37.

Lewis, G. R., \& Demarest, B. A. (1996). Integrative theology. Zondervan.

Lim, D. S. (2004). Cho younggi's charismatic leadership and Church Growth. Great Commission Research Journal, 15(2), 3-28.

Malphurs, A. A., \& Penfold, G. E. (2014). Re:Vision: The key to transforming your church. Baker.

McGavran, D. A. (1955). The bridges of God: A study in the strategy of missions. World Dominion Press. 
McGavran, D. A., \& Wagner, C. P. (1990). Understanding Church Growth (Third ed.). Eerdmans.

McIntosh, G. L. (1999). One size doesn't fit all: Bringing out the best in any size church. Revell.

McIntosh, G. L. (2003). Biblical church growth: How you can work with God to build a faithful church. Baker Books.

McIntosh, G. L. (2009). Taking your church to the next level: What got you here won't get you there. Baker Books.

Moberg, D. O. (1962). The church as a social institution: The sociology of American religion. Prentice-Hall.

Moon, W. J. (2020). Alternative financial models for churches and church plants: When tithes and offerings are not enough. Great Commission Research Journal, 12(1), 19-42.

Patton, M. Q. (2014). Qualitative research \& evaluation methods: Integrating theory and practice (4th, Ed.). Sage Publications.

Rainier, T. S. (2020). The post-quarantine church: Six urgent challenges and opportunities that will determine the future of your congregation. Tyndale Momentum.

von der Ruhr, M., \& Daniels, J. P. (2012). Examining megachurch growth: Free riding, fit, and faith. International Journal of Social Economics, 39(5), 357-372.

Wagner, C. P. (1989). Strategies for church growth: Tools for effective mission and evangelism. Wipf and Stock Publishers.

Wagner, C. P. (1990). Church planting for a greater harvest: A comprehensive guide. Regal Books.

Wicker, A. W. (1969). Size of church membership and members' support of church behavior settings. Journal of Personality and Social Psychology, 13(3), 278.

Wicker, A. W. (1985). Getting out of our conceptual ruts: Strategies for expanding conceptual frameworks. American Psychologist, 4O(10), 1094-1103.

Wuthnow, R. (1994). Sharing the journey: Support groups and America's new quest for community. Simon and Schuster. 